ARTICLE

https://doi.org/10.1057/s41599-020-0393-8

\title{
Is Lennie a monster? A reconsideration of Steinbeck's Of Mice and Men in a 21st century inclusive classroom context
}

\author{
Clare Lawrence (iD $^{1 \star}$
}

\begin{abstract}
Of Mice and Men remains a staple text in schools in both the United States and United Kingdom, where both neuro-typical and disabled pupils encounter it. The character of Lennie has learning difficulties and also-as identified by some researchers-exhibits many characteristics of autism. Although the novella is hailed as a modern classic, there are aspects in Steinbeck's portrayal of Lennie as un-human, 'othered' from the other characters in the book and demonised as animal-like that merit challenge if they are to be encountered in the modern classroom. This study asks, 'If Lennie is a monster, what does that mean for pupils' understanding of autism and intellectual disability both inside and outside the classroom?' It considers the portrayal of Lennie from within its origins in the Eugenics movement of the 1930s, the effect of reader sympathies with George in the final action of the book and the moral effect of the 'Briseño' factor, used in Texas to decide on a prisoner's suitability to face the death penalty. The importance of teachers' awareness of disability issues and language when teaching texts of this kind and of the positioning of texts within the disability awareness curriculum is discussed.
\end{abstract}




\section{Introduction}

In books [young people] are meeting extremely compelling images of life that will undoubtedly influence the crystallisation of their ultimate attitudes, either of acceptance or of rejection.

(Rosenblatt, 1938, p. 20 in Garrison, 2008, p. 3).

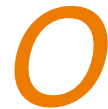

$f$ Mice and Men has been a staple schoolroom text in both the United States and United Kingdom for decades. In 2014 it was identified that 'over $90 \%$ of schools teach Of Mice and Men to their GCSE students' (BBC News, March 25 th, 2014). The text was subsequently removed from the GCSE examination syllabus in the UK in favour of books by British writers. As such it has lost its central position in many school curricula, yet is retained by many schools as a text in Key Stage 3 (Kneen et al., 2019). Here it is not subject to the same examination constraints in its teaching, potentially liberating it for new considerations, not least that as an exploration of disability issues.

Although the National Curriculum requires schools to include Citizenship in their teaching (DfE, 2013), including the need for 'mutual respect and understanding' (DfE, 2013, p. 3), it does not specify disability awareness and understanding within this. A survey of pupils aged 14-16 (McCarthy et al., 2008) recorded that over half had not learned about disabled people or people with learning difficulties within the previous academic year. It is also the case that in 2018 the National Audit Office reported that over $70 \%$ of secondary schools were identified as Academies (National Audit Office, 2018), and are therefore not required to follow the National Curriculum. All schools in England are required to teach Fundamental British Values, including 'an understanding of the importance of identifying and combatting discrimination' (DfE, 2014 , p. 6). However, this is framed within a cultural and faith context, and does not explicitly include disability awareness. Pupils' encounters with disabled characters as portrayed in literature are likely therefore to remain an important element of their disability understanding.

Of Mice and Men remains a much-loved and valued text. As Ryan Wilson, writing in The Guardian (8th May, 2016) puts it:

Everything you'd want to teach a child about literature is there. Symbolism, structure, pathos, characterisation, imagery: it's got it all. More than that, the themes of hope, friendship, loyalty and vulnerability speak to students and their very modern concerns.

The text is accessible, engaging and powerful as a piece of literature. As such, it may provide a useful vehicle for the exploration from a disability studies perspective to challenge societal stereotypes and prejudices. Of course, it is important within such an exploration not to lose sight of Steinbeck's original voice as Steinbeck did not create Lennie to be an educational resource around disability.

It is not Steinbeck's responsibility as an author to cast Lennie in a positive or negative light, it is the teacher's task to unpack Steinbeck's novella and representations of Lennie.

(McCabe, 2014, p. 16).

As well as being a teaching responsibility to challenge pupils' concepts of disability regardless of authorial intention, as will be argued in the course of this paper characters in books can sometimes 'take on a life of their own' never intended by the author. Lennie exists now in a 21 st century context in our classrooms. The move 'down' in UK schools for Of Mice and Men from GCSE text to KS3 text gives teachers greater freedom and allows exploration of $O f$ Mice and Men to move beyond curriculum concerns. Rather than an 'exam text', one approach available to teachers is to use it to explore, consider and challenge the portrayals of disability within it, both within historic and current contexts. As McCabe (2014) suggests, 'The questions that a teacher does or does not ask may profoundly shape students' views of disability, for better or for worse' (p. 16). Discussion of the depiction of Lennie as 'other', and the implications of this for all autistic and/or intellectually disabled people may find a space.

The inevitable question in all classroom readings of Of Mice and Men is to what extent George's action in killing Lennie at the end of the book can be justified. This is 'the ethical debate that has engaged generations of critics (and generations of high school students)' (Loftis, 2015, p. 71). This study asks the question of how that discussion may be most potently framed within a modern 21 st century context and gives a detailed examination of how the text might be used as a vehicle for disability awareness debate within the classroom. As such it is new, it expands upon current research and thereby makes an original contribution to the field.

\section{Methods}

This analysis of the portrayal of disability in Steinbeck's novel of Mice and Men for use in the classroom uses the theoretical framework of Disability Studies, and specifically the Social Model of disability, to explore the novella as it can be understood in the 21 st century classroom and, in particular, how the final action of the book might be framed. Disability Studies as a movement developed from the late 20th century to provide 'an epistemology of inclusion and integration' (Linton, 1998, p. 526) that challenges societal conceptualisation of disability. It positions previous understanding of disability as 'social oppression involving the social imposition of restrictions of activity on people with impairment' (Thomas, 2007, p. 73), and seeks to question previously held notions and perceptions. As such, re-examination of texts through a Disability Studies lens allows a re-evaluation of those texts, while simultaneously recognising their historical and contextual significance. The Social Model of disability challenges the concept that disability is understood as an impairment within an individual but instead suggests a model where 'disability (as opposed to impairment) is considered to be imposed over and above impairment by societal barriers' (Chown et al., 2017, p. 724). This study encourages students to consider how much the character of Lennie is inherently impaired by his disability, and how much he is disabled by other characters' responses to his impairments. It considers how the final act of the book can be explored in the classroom within a 21 st century moral and ethical framework and how this might be used to challenge ableist rhetoric in students and society.

As Kennedy and Menten (2010) indicate, 'whether we talk about it or not, (dis)ability issues permeate our classes, our teaching, and our students' experiences in and outside of the classroom' (p. 61). Of Mice and Men is a story about an intellectually disabled man. Lennie's disability is central to the plot; if he were not intellectually disabled, the story would simply not work. It has also been suggested (Loftis, 2015, 2016) that Lennie exhibits characteristics of autism. His love of repetition and use of echolalia, his idiosyncratic memory, his sensory attraction to things that are soft and his over-load (or 'meltdown') in the face of noise or panic in others may all position him within a modern understanding of an autistic portrayal. Steinbeck did not create the character from a position of sophisticated understanding of autism as the condition was not identified by Leo Kanner until 
1943 (Wing, 1996). However, he based his portrayal on a real person (Steinbeck in Fensch, 1988), and he clearly had very distinctive characteristics in mind in his descriptions. '[Steinbeck's] depiction of Lennie highlights traits strongly associated in the public mind with autism' (Loftis, 2016, p. 474).

This current study builds securely on previous work on the portrayal of autistic characters within texts by Loftis $(2015,2016)$. As an autistic researcher, Loftis is strongly positioned to explore the implications of an autistic reading of the character Lennie. Best practice in autism research as described by Chown et al. (2017) identifies as important that 'a researcher with autism either identifies and defines the matter(s) requiring investigation or confirms the identification and definition of the problem by others' in autism research (Chown et al., 2017, p. 727). Loftis confirms the importance of 'illuminating the space between stereotype and personal identity' (Loftis, 2015, p. 2) and how 'stories ... matter. They influence the way we think about people with autism [and] the way we think about disabled people as a culturally minority group' (Loftis, 2015, p. 2).

\section{Discussion}

Consideration of Of mice and Men through a disability studies lens results in both an understanding of the portrayal of Lennie as un-human and in a perception of inhumanity in the societal context-both contemporary and modern-in which the character is set. This is explored in this study in two sections: (i) The monster within: Lennie and (ii) The monster without: contextualising Lennie within society.

The monster within: Lennie. Lennie from the very beginning is portrayed as 'other'; indeed, he is introduced in terms of how he is not like George:

Behind [George] walked his opposite, a huge man, shapeless of face, with large, pale eyes, with wide, sloping shoulders; and he walked heavily, dragging his feet a little, the way a bear drags his paws.

(Steinbeck, 1937a, p. 2)

Lennie follows George, even when the path widens to allow more space. George forces Lennie to hand over a dead mouse that is 'not fresh', an action that invites approval from the reader. George provides Lennie with food in an action designed to emphasise that Lennie would be helpless without him ('How'd you eat. You ain't got sense enough to find nothing to eat.' (Steinbeck, 1937a, p. 13)). At a fundamental level Lennie lacks agency-and when he does attempt to 'do his own thing', whether to retrieve the dead mouse, smuggle the puppy into the bunkhouse or touch the girl in Weed's red dress, George retakes control. Lennie is completely subordinated to George ... the reader is subtly guided to empathize with George and to see Lennie only through his relationship with his neurotypical friend' (Loftis, 2016, p. 472). Furthermore, the physical descriptions of Lennie mark him out as different. His size is constantly emphasised; he is repeatedly described as 'huge' and as being a 'big guy'/'big bastard'/'big son-of-a-bitch'. His portrayal as 'shapeless', McCabe suggests, 'lends itself to Steinbeck's representation of his disability. Lennie is vague and nebulous, much like what his mind is assumed to be' (McCabe, 2014, p. 14). This positioning of Lennie as 'other' has its roots in philosophy:

From Plato and Aristotle to Kant and beyond, philosophers have prized rationality as the defining factor that makes a human being human ... Intellectually disabled individuals have caused philosophers to question the validity of rationality as the primary determinate of humanity; [such] philosophers may not view those with intellectual disabilities as human at all.

(Jensen-Moulton, 2012, p. 145).

Lennie is further identified as un-human through the many descriptions of him as animal. He is described, variously, as having paws, as growling, as moving as a bear moves, as drinking like a horse, as being as strong as a bull, as being like a terrier with a ball. Each of these dehumanise him. Some animal rights activists (for example, Singer, 1995; McMahan, 1996, 2002) have argued that people with intellectual impairment have no innate right to be treated better than non-human animals with similar cognitive functioning. This position argues that 'to grant human beings higher moral status than nonhuman animals with ... "comparable" intellectual ability is arbitrary and unjustified' (Carlson and Kittay, 2009, p. 311). According to these philosophers, 'the intellectually disabled individual has even less of a claim on humanity than do some highly intelligent nonhuman animals' (Jensen-Moulton, 2012, p. 146). In this philosophical position, Lennie is truly un-human.

Lennie is not unique in the text as being described in animalistic terms. Steinbeck is creating a world where men (and women) are part of nature, with little human agency effective in impacting their lives and where the characters are blown like tumbleweeds across a dusty and barren landscape. The reader is led to believe at the opening of the narrative that the rootlessness of the two men described is due to Lennie, and to his actions in Weed. However, the reader quickly understands that the opposite is true; George's care of Lennie is his rooting factor. Slim recognises this and sanctions it and briefly a similar stability seems to be offered to other characters. However, the characters' natures and their place within a natural order do not allow this. 'In the light of the naturalistic view the characters in Of Mice and Men ... are reduced to animals, which look for their living and struggle for their existence' (Abdullah, 2010, p. 569). Each of the characters is close to animals; Lennie is just closer. His strength, unmediated by rational understanding, makes him less human than the others.

Part of Lennie's animalism is his affinity with animals and this further positions him as animal-like; as Iyer (2007) suggests, 'resemblance to and kinship with animals is often called forth to emphasise the difference of people with intellectual disabilities and signal that they are not quite human' (p. 129). Lennie is not given sufficient human status to be able to care for animals as lesser than him. That status is given most powerfully to Slim, 'the prince of the ranch, capable of driving 10, 16, even 20 mules with a single line to the leaders' (Steinbeck, 1937a, p. 36). Slim has control over the mules, over the puppies to decide which live and which die, over the fate of Candy's old dog and-ultimately-over that of Lennie. Although Slim can choose life or death, Lennie is portrayed as a killer without choice. He was given mice by his late Aunt Clara, but 'always killed 'em' (Steinbeck, 1937a, p.10). He kills the puppy when he 'made like I was gonna smack him ... an' ... I done it. An' then he was dead' (Steinbeck, 1937a, p. 95). He plans to 'tell George I foun' it dead' (as he did with the mouse at the very opening of the book) and does in fact 'get away' with this when larger events overtake this one. The reader is led to understand that even should Lennie have achieved his dream of tending the long-haired rabbits, this would inevitably have resulted in their deaths. Lennie is not positioned as sufficiently human to be able to take care of animals.

$\mathrm{He}$ is also positioned as being dangerously 'at large', not contained in an institution and only barely controlled by George. 'Steinbeck's work emanates from an era when intellectually disabled individuals were primarily regarded as burdens on 
society and were often institutionalised' (Jensen-Moulton, 2012, p. 130). The institutionisation of individuals with intellectual impairment would have meant that to the original reader, George and Lennie's relationship would have seemed strange. The boss questions it when they first arrive at the ranch ('what stake you got in this guy? You takin' his pay away from him?” (Steinbeck, 1937 a, p. 24)) and Steinbeck has George justify the relationship to Slim: "You guys travel around together?" ... "Sure," said George. "We kinda look after each other." (Steinbeck, 1937a, p. 38). Lennie's strength suggests that George struggles to control him ('There ain't nobody can keep up with him. God awmighty, I never seen such a strong guy' (Steinbeck, 1937a, p. 42)), as he is aware that Lennie could 'bust every bone in my body jus' with his han's' (Steinbeck, 1937a, p. 44). In order to stop Lennie after he has set him on Curley he has to slap him in the face 'again and again' (Steinbeck, 1937a, p. 69) and reports that he 'socked him over the head with a fence picket' during the incident in Weed in order to make Lennie let go of the girl's dress (Steinbeck, 1937a, p. 46). The reader is made aware that Lennie is barely contained and 'the disastrous results of [Lennie's] relative freedom reinforce the notion that he should have been segregated from society in the first place' (Jensen-Moulton, 2012, p. 130).

In so far as Lennie is positioned as human it is as a child. He is told that he is a 'good boy' by George, is described as 'giggling' (Steinbeck, 1937a, p. 7, p. 115), as 'blubberin' like a baby' (Steinbeck, 1937a, p. 10), and as being 'jes' like a big baby' (Steinbeck, 1937a, p. 98). When the pair arrive at the ranch, George 'draws on Lennie's childlike qualities to make him seem less threatening' (Chivers, 2003), telling Slim, the leader of the ranch hands, “'Sure he's jes' like a kid. There ain't no more harm in him than a kid neither, except he's so strong"' (Steinbeck, 1937a, p. 47). Lennie's obedience (and at times his disobedience, transparent to George), his mimicry of George's actions and his enthusiasm are all childlike. In their article, Infantilizing Autism (2011), Stevenson, Harp and Gernsbacher describe that:

Adults with disabilities in general, and those with developmental disabilities in particular, have long been treated as childlike entities, deserving fewer rights and incurring greater condescension than adults without disabilities. The stereotype of the "eternal child" has burned a disturbing path through history and continues to wreak havoc in arenas ranging from employment discrimination to forced sterilisations.

(Stevenson et al., 2011).

However, Lennie is also positioned as menacing. Chivers (2003) identifies that 'as the novella progresses, the comparisons to animals are increasingly sinister, rendering [Lennie] not just animalistic, but also savage' (no page). When Crooks suggests that George might have got injured in town, Lennie becomes threatening:

Suddenly Lennie's eyes centered and grew quiet, and mad. He stood up and walked dangerously toward Crooks. "Who hurt George?" he demanded. Crooks saw the danger as it approached him. He edged back on his bunk to get out of the way. "I was just supposin'," he said. "George ain't hurt. He's all right. He'll be back all right.” ... Lennie growled back to his seat on the nail keg.

\section{(Steinbeck, 1937a, p. 79).}

This potential violence when he feels George to be threatened mirrors the incident that acted as the source for Steinbeck's portrayal of Lennie. When working as a migrant worker himself Steinbeck had witnessed an attack:
Lennie was a real person. He's in an insane asylum in California right now ... he didn't kill a girl. He killed a ranch foreman. Got sore because the boss had fired his pal...

(Steinbeck in Fensch, 1988, p. 9).

Steinbeck's version of Lennie does not kill in anger, although his menacing stance with Crooks when he believes George to be threatened suggests that he might. Instead, Steinbeck allows the incident to take on an element of sexuality. Lennie's sexuality is problematic to the characters throughout the novel. George's emphasis that Lennie is childlike seeks to deny it, and Lennie is excluded from the men's visit to the 'cat house'. George refuses to discuss what he had said (presumably a sexual remark) about the girls in Murray and he is uncomfortable when Lennie shows signs of sexuality. When 'Lennie's eyes moved down over [Curley's wife's] body' George chastises him for his behaviour complaining that 'when she was standin' in the doorway showin' her legs, you wasn't lookin' the other way' (Steinbeck, 1937a, p. 35). People with intellectual disabilities are often portrayed as either sexual innocents or sexual predators (Garrison, 2008):

Cultural depictions of people on the [autistic] spectrum display the two stereotypical extremes accorded by our society to disabled sexuality in general (people with disabilities are imagined as either asexual or as hypersexual/sexually deviant).

(Loftis, 2016, p. 475).

Within this, Lennie's positioning is ambiguous. The reader understands that Lennie just wanted to touch the girl in Weed's red dress, but the girl 'rabbits in an' tells the law she been raped', resulting in the 'guys in Weed start[ing] a party out to lynch Lennie' (Steinbeck, 1937a, p. 46). In one sense, then, Lennie is positioned as 'a violent sexual predator' (Gurko, 1998, p. 62) and in another as a man with deviant sexual needs: 'neurotypical readers are not likely to share Lennie's intense sensory responses' (Loftis, 2016, p. 475). His attraction to both the girl in Weed's dress and to Curley's wife's hair is sensory. His innocent wish to 'pet' soft things is 'other' in this context and, although Steinbeck makes it clear that the killing of Curley's wife is accidental, it is nevertheless as a result of his autistic traits. 'A murder driven by sensory needs greatly reduces Lennie's agency: he seems to be controlled by his impairment' (Loftis, 2016, p. 475). Nor is Lennie's motivation for the 'attack' clear to the other characters in the book nor, by inference, to wider society; the innocence of his intention is in this way undermined.

Steinbeck uses physical description of Lennie to indicate his intellectual state. This is a calculated technique:

Describing the physical form of a character with intellectual disability has the advantage of visually delineating the abstract concept of the disability ... It also plays on the often unspoken assumption that people are as people look. This belief is so widespread that people with visible anomalies are often assumed to be intellectually disabled, even if they are not.

(Iyer, 2007, p. 129).

Lennie's arms do 'not swing at his sides, but [hang] loosely' (Steinbeck, 1937a, p. 2); he watches George 'with open mouth' (Steinbeck, 1937a, p. 20) and flaps 'his big hands helplessly' (Steinbeck, 1937a, p. 75), each description feeding the potentially dangerous assumption that that learning disability and/or autism can be 'seen'. Although some conditions that result in learning 
disability do include physical characteristics, autism is not a set of behaviours and as such there are no physical traits or characteristics of autism: 'Although some behaviours may be associated with being autistic, none of them is universal and certainly none of them is exclusive' (Beardon, 2019, private correspondence $\left.\mathrm{e}^{1}\right)$. However, each of the descriptions of Lennie's physical behaviour that Steinbeck gives in the novella acts as a stage direction in Steinbeck's 'novel-play', a book written 'with the stage in mind' (Perry, 1968, p. 1312). Steinbeck's idea with the novella was to 'write a play in the form of a novel ... [where I] constructed it in scenes and filled in the character descriptions and painted in the background' (Steinbeck in Fensch, 1988, p. 9). The character directions in the book also provide support for the (presumably non-disabled) actor playing Lennie in the stage version written the same year, and invite that actor to indicate, physically, that Lennie has intellectual disabilities through stereotypical actions and behaviours.

The monster without: contextualising Lennie within society. The positioning of Lennie as irredeemably 'other', as un-human and animal-like both enables the final action of the book to take place and, importantly, for the reader to condone it. This positioning is validated by Steinbeck through the person of Slim, the clear authority figure of the book. That Lennie's killing as justified has been prepared for the reader in the killing of Candy's dog, when Slim agrees the action, resulting in Candy looking 'helplessly at him, for Slim's opinions were law' (Steinbeck, 1937a, p. 50). Lennie's death is similarly sanctioned by Slim in the novella. In the stage version published by Steinbeck in the same year Steinbeck makes this affirmation of the unavoidability of the killing even clearer by having Slim condone it before the event. The mob are searching for Lennie but are misdirected away by Slim, leaving only him and George on stage. 'Where is he?' Slim asks, and George indicates Lennie's hiding place. 'You want I should go away?' Slim asks. He then 'starts away, comes back, tries to say something, instead puts his hand on George's shoulder for a second then hurries off upstage' (Steinbeck, 1937b, p. 85).

Eugenics themes run strongly through the narrative of Of Mice and Men. Slim drowns four smaller puppies in order to enable the bigger ones to thrive; Candy's old dog is shot because it is old and blind and-more important to Carleson who instigates the killing -it smells. Although there are other disabled characters in the novella (Candy has lost a hand and Crooks' has a bent back) in each case this is as the result of an accident and the character was born 'normal'. Given the eugenics obsession with genes and breeding, this would have rendered them less threatening.

Sterilisation or even eugenic elimination of those members of society deemed "subnormal" ... represented a particularly U.S. approach to dealing with disability ... California's eugenics laws allowed for the sterilisation of more than 21,000 people between 1907 and 1939 in order to prevent the passing of "feeble-mindedness" from generation to generation.

(Jensen-Moulton, 2012, p. 130).

George shows awareness of Lennie's vulnerability to eugenics scrutiny when he lies to the boss that Lennie was kicked in the head as a child; he is aware that brain injury is less threatening to society and more socially acceptable than developmental delay or autism. 'George tries to protect [Lennie] ... by telling the other ranch hands that Lennie was kicked in the head ... when he was a child, as though that makes his disability more noble and acceptable' (McCabe, 2014, p. 17). However, Steinbeck also makes clear to the reader the true nature of Lennie's disability ("I wasn't kicked in the head with no horse, was I, George?" "Be a damn good thing if you wa" George said viciously. "Save ever'body a hell of a lot of trouble"' (Steinbeck, 1937a, p. 26).

Steinbeck positions the story so that the reader's sympathies at the end of it lie with George, despite and indeed regarding his killing of Lennie. George kills Lennie in what is positioned as a kindly termination, a 'putting out of his misery', as one might an animal. 'Many readers see George ... as Lennie's "rescuer" (Loftis, 2016, p. 478). George is in a carer-almost a parentalrole, and he chooses to kill Lennie to 'protect' him. Loftis identifies that 'Lennie's death is 'authorised' by cultural discourses that depict autistic people as ... [lacking] human subjectivity' (Loftis, 2016, p. 470). A common argument put forward in classrooms is that George is undertaking a 'mercy killing' because he has no choice. Steinbeck allows little possibility of a safe future for Lennie if he is detained. As Crooks taunts Lennie, “'They'll take ya to the booby hatch. They'll tie ya up with a collar, like a dog “' (Steinbeck, 1937a, p. 79). Although George tries to reassure himself ("Maybe they'll lock 'im up an' be nice to 'im" Steinbeck, 1937 a, p. 103), the grimness of the conditions for those with learning disabilities detained in 1930s America is often cited by students as justification for George's action.

Students discussing the ending of the book in a 21st century classroom might consider this justification when aligned with care of learning disabled and autistic people in the present day. The recent Joint Committee report on the detention of young people with learning disabilities and/or autism (November 2019) indicates:

(T)he detention of young people with learning disabilities and/or autism not only threatens their rights to private and family life [Article 8 European Convention on Human Rights] and their right to freedom from inhuman and degrading treatment [Article 3 ECHR] but also their right to liberty and security [Article $5 \mathrm{ECHR}$ ] and in some cases their right to life [Article 2 ECHR].

(House of Commons and House of Lords Joint Committee on Human Rights, 2019, p. 5).

Students may argue that to tie someone with learning disability or autism up 'like a dog' as Steinbeck's world describes meant that death-in a 1930s context-was a viable alternative. However, this line of argument becomes far more uncomfortable when contextualised in current conditions, as described by a father of an autistic child:

Between 11th June and 8th November 2018, she was physically and forcibly restrained 18 times, including use of prone restraint on a hard floor. Brutal, frightening and traumatic for a vulnerable autistic child (clearly in fight or flight response). During the use of prone restraint, she sustained physical injuries that were neither reported to me or raised as safe guarding concerns to the [Local Authority Designated Officer].

The father of an autistic child who has been an in-patient in two psychiatric Assessment and Treatment Units (ATUs).

(House of Commons and House of Lords Joint Committee on Human Rights, 2019, p. 35).

Figures from NHS Digital (Dahlgreen, 2019) show that in June $2019,11 \%$ of people with learning disabilities and/or autism in inpatient units/wards experienced some form of restrictive intervention and that number has been increasing in recent years. 
These restraints can involve sedation with strong drugs (chemical restraint), the use of belts, cuffs and restraints for behavioural control (mechanical restraint), and being forced to the floor in a chest-down position (prone restraint).

(Dahlgreen, 2019, on-line).

The alternative to detention for Lennie in the course of the novella has been a form of care in the community where George 'looks after' him. The reader is encouraged to validate this care despite the many insults that George levels at Lennie, his mimicry of him, his taunts and his report of the near drowning incident in the past. Nor does George prevent other characters from abusing Lennie, most notably Curley's attack and Crooks' taunting of him over George's absence. The reader is also invited to 'over-look' George's final act of violence. The classroom debate is likely to be enriched by consideration of the vulnerability of people with learning disability and/or autism to acts of abuse and acts of violence. People with learning disability and/or autism are at much higher risk of violence than their non-disabled peers (Hughes et al., 2012; Chaplin and Mukhopadhyay, 2018), with $73 \%$ of people with learning disability and/or autism reporting being victimised because of their disability, including experiencing verbal, physical and sexual assault and with over half experiencing such acts within the last year (Dimensions, 2016). 'Many disabled people experience fear, harassment and occasionally violence' (Hall, 2019, p. 249). In one study (Luciano and Savage, 2007), $83 \%$ of young people with learning difficulties reported experiencing bullying and in another (Bejerot and Mörtberg, 2009) $80 \%$ of children with autism combined with other characteristics were found to have been bullied.

As well as being an intrinsically violent act, George's murder of Lennie as a 'mercy-killing' has disquieting echoes in the world outside the book. 'Violence against people with autism is often perpetrated by family members' (Loftis, 2016, p. 478) and 'autistic people are particularly likely to be the victims of filicide [when a child is killed by its parents]' (Loftis, 2016, p. 470). What is more, the focus and sympathy regarding these killings in the majority of these cases ... is not on the child who has died, but rather on the parent' (Murray, 2008, p. 168). Like those of the reader in $O f$ Mice and Men, the public has its sympathies tuned towards the perpetrator: 'media coverage that is sympathetic to autistic filicide [presents] parents as overwhelmed by their children's care [and depicts] murder as an act of mercy' (Loftis, 2016, p. 471). The focus is turned away from the victim; instead, 'too often, stories of filicide focus on how "stressed" the parent or caregiver was' (Swenson, 2019, p. 142). The public is positioned as 'understanding':

When a child without a disability is murdered by their parents, everyone stands united in condemnation. No one attempts to understand, justify, or explain the murder. No one expresses sympathy for the murderer. No one argues that every parent has had moments or thoughts like that ... The crime is punished harshly, and the victim is remembered and mourned.

When someone with a disability is murdered by their parents, the opposite happens.

(Gross, 2012, p. 5).

Autistic people are positioned in this narrative as 'other', allowing society to empathise with the perpetrator. This narrative needs to be challenged in schools. In the Autism Self Advocacy Network Anti-filicide Toolkit there are a number of suggestions made about how to write about the murder of a disabled person by their parent or carer. These include that the writer should humanise the victim, should use the victim's name, should mourn the victim, should not imply that the person is better off dead and should use the term 'murder' rather than 'mercy-killing'. Above all, 'the reader should get the sense that the victim was a real human being' (Gross, 2012, p. 8). Each of these could be usefully applied to discussions in the classroom about Lennie's death as all too often the framing of discussion around the ending of the novella is 'not really about Lennie's death so much as it is about George's decision' (Loftis, 2016, p. 478).

\section{Conclusion}

This study aims to enhance our understanding of what we can do to support children's understanding of autism and intellectual disability. Removing Lennie from his context in the book and arguing for the effect of the character in a 'real world' scenario may be uncomfortable for some readers as it is to remove the character from Steinbeck's original intention, and from a time when society's perceptions of the place of disabled people was, at least in theory, very different. However, it remains a valid undertaking not least because characters from fiction may sometimes take on a life of their own, unimagined by their creator.

In 2002, the Supreme Court in America barred the execution of mentally disabled people. In this respect this group is given protection in their positioning as un-human: only a human being capable of rational thought and moral understanding is deemed 'fit' for execution. At this ruling 'a lot of leeway [was left] for individual states to determine just how they would define intellectually disabled' (Liptak, 2016). Texas, somewhat controversially, decided to use what became known as the Briseño factors: 'non-scientific standards inspired by the character Lennie in Of Mice and Men' (Long, 2013, p. 859) to make this judgement. The Court of Criminal Appeals stated that their role was to:

"define that level and degree of mental retardation at which a consensus of Texas citizens would agree that a person should be exempted from the death penalty." As an example of an individual that most Texans would agree should be exempt, the court cited Lennie, the fictional character in Steinbeck's Of Mice and Men.

\section{(Crowell, 2015, p. 749).}

This use of this fictional character to decide the fate of humans was fiercely contested by Steinbeck's son when it was last used to justify the execution of Marvin Wilson on 7th August 2012. Wilson was judged to have an IQ of 61 but failed the 'Lennie test'. Thomas Steinbeck stated that his father would be 'deeply angry and ashamed to see his work used in this way" (Thomas Steinbeck in Khomami, 2012). Lennie's fate in the novella makes the Briseño factors even more bizarre:

Setting aside the fact that Lennie Small is, in fact, murdered by his only friend, George Milton ... one wonders what business Lennie has appearing as a limit case in a legal instrument designed to measure intellectual disability and fitness for capital punishment? (Kupetz, 2016, p. 3).

Briseño was more recently contested and the objection upheld (Moore vs. Texas, 2017). It is interesting to note, however, that according to it, in the country in which the book is set 'justice' for Lennie's actions would not constitute the death penalty; for George's actions, on the other hand, it would.

Consideration of Lennie away from the social context of the book, and without consideration of Steinbeck's authorial 
intention in his creation, does therefore have precedent. However, even within the confines of the novel, 'justice' for Lennie is clearly lacking. At the end of the novella the reader is very clear about George's future. He rejects the vision still held onto by Candy: '"You an' me can get that little place, can't we George? You an' me can go there an' live nice, can't we, George? Can't we?" (Steinbeck, 1937a, p. 103). Instead there is complete clarity about how George will now live: 'I'll work my month an' I'll take my fifty bucks an' I'll stay all night in some lousy cat house..." (Steinbeck, 1937a, p. 103). There is no suggestion at any point that George will face criminal investigation, imprisonment or any other sanction for his crime. The law, in the shape of the deputy sheriff $\mathrm{Al}$ Wilts has been sent for, but this is with regard to the death of Curley's wife. Punishment for this, even though the reader knows it to have been accidental, is potentially that Lennie be 'put in a cage' (Steinbeck, 1937a, p.106), 'lynched' (Steinbeck, 1937 a, p. 103), shot 'in the guts' (Steinbeck, 1937a, p. 105/106) or-as transpires-shot in the back of the head having been 'essentially tried by a jury of one peer and sentenced to death' (Jensen-Moulton, 2012, p. 145). George, on the other hand, seems set to escape any retribution; it is this lack of sanction by the law for George's action that positions his victim most powerfully as un-human.

Pupils' responses to portrayals of disability in literary texts are important.

'The Disability Equality Duty (DED) ... includes a requirement to promote positive attitudes towards disabled people. Schools are well-placed to proactively inform and raise awareness among children, young people and their families'

\section{(McCarthy et al., 2008, p. 2).}

Garrison (2008) studied the perceptions of disability of 28 female and 20 male adolescents aged 14 or 15 on reading the text of Of Mice and Men. The results were disturbing. The young people frequently responded to the construct of disability as presented in Of Mice and Men as being 'other' to their own experiences. They described disability as being 'abnormal' or 'inferior' and indicated that they were less likely to identify with disabled characters (Garrison, 2008, p. 195). The results of the study 'revealed that these adolescent readers reported negative perceptions of the characters with disabilities and their relationships within the novel that align with eugenic beliefs about people with disabilities when responding to the novel Of Mice and Men' (Garrison, 2008, p. 191). Garrison highlights the importance of 'teachers who are knowledgeable of disability studies and ableism [who] can foster their students' ability to critically analyse disability as a social construct in literature and in society' (Garrison, 2008, p. 205).

This study builds on the work of Sonya Loftis who, as an autistic researcher, is powerfully placed to discuss the portrayal of Lennie within a modern reading of the book. One of the implications of a view of autism as one of deficit is 'the exclusion of autistic voices from processes of knowledge production' (Milton and Bracher, 2013, p. 61). Good practice in autism research is beginning to recognise the importance of these voices:

Autistic researchers have begun to contribute to the debates over aspects of autism, to research led by non-autistic scholars, and to the development of our understanding of autism.

\section{(Chown et al., 2017, p. 721).}

Also important in Loftis' contribution is her position as Professor of English. One of the fundamental issues regarding the portrayal of Lennie in Of Mice and Men lies in the way that Steinbeck positions the reader from the very beginning to identify with George. It is inconceivable to Steinbeck that readers will identify themselves with Lennie; people 'like Lennie', he implies, will not read the book. As important as an autistic researcher at the heart of this study is awareness of the place of autistic and learning-disabled pupils in the classroom debate. Moderate learning difficulty (MLD) was recorded as the most common primary type of need of pupils with Special Educational Needs in England in 2018, with autism identified as the most common primary type of need for pupils with a statement or EHC plan (DfE, 2018). Pupils with both MLD and with autism will encounter the character of Lennie in Of Mice and Men and hearing their views on the positioning of Lennie and the place of that position within a modern cultural context is essential. Equally, teachers both with and without autism will teach the book (Lawrence, 2019). Loftis, other autistic academics and autistic teachers each help to reposition the classroom response to one where Steinbeck's instinctive positioning of Lennie as 'other' is increasingly challenged.

Brueggemann (2008) identifies how intrinsic disability issues are to the classroom:

Disability, unseen, unacknowledged, and unexamined, is already always present in the [classroom]. It is present as students in our classes, in the language we use, the ways that we teach and tutor, even in physical spaces and institutional structures (Brueggemann, 2008, p. 61).

To deny a disability studies examination of Lennie in Of Mice and Men is to maintain a position where disability is 'unseen, unacknowledged, and unexamined'. How much richer it is to embrace the issues and questions that such an examination brings and through it to re-establish Of Mice and Men as a central and important text at the core of the modern curriculum.

\section{Data availability}

Data sharing not applicable to this article as no datasets were generated or analysed during the current study.

Received: 7 September 2019; Accepted: 9 January 2020; Published online: 31 January 2020

\section{Notes}

1 Dr. Luke Beardon, Personal Communication, 28th August, 2019.

\section{References}

Abdullah YM (2010). The Naturalistic Implications in John Steinbeck's Of Mice and Men. J Al_Anbar Univ Language Literature, (3), 566-573. https://www. iasj.net/iasj?func $=$ article $\&$ aId $=64107$

Bejerot S, Mörtberg E (2009) Do autistic traits play a role in the bullying of obsessive-compulsive disorder and social phobia sufferers? Psychopathology 42(3):170-176

Brueggemann BJ (2008). Disability and the teaching of writing: a critical sourcebook. In: Lewiecki-Wilson C (ed.). Bedford/St. Martin's, Boston, p. 1

Carlson L, Kittay EF (2009) Introduction: rethinking philosophical presumptions in light of cognitive disability. Metaphilosophy 40(3-4):307-330

Chaplin E, Mukhopadhyay S (2018) Autism spectrum disorder and hate crime. Adv Autism 4(1):30-36

Chivers S (2003). Disability studipes and the Vancouver opera's Of Mice and Men. Disabil Stud Q 23(1)

Chown N, Robinson J, Beardon L, Downing J, Hughes L, Leatherland J, MacGregor D (2017) Improving research about us, with us: a draft framework for inclusive autism research. Disabil Soc 32(5):720-734

Crowell H (2015) The writing is on the wall: how the briseno factors create an unacceptable risk of executing persons with intellectual disability. Tex L Rev $94: 743$ 
Dahlgreen W (2019). The failings in learning disability services in six charts. BBC News. https://www.bbc.co.uk/news/health-48355111 Accessed 3 Nov 2019

Department for Education (2018). Special educational needs in England. https:// assets.publishing.service.gov.uk/government/uploads/system/uploads/ attachment_data/file/729208/SEN_2018_Text.pdf Accessed 29 Oct 2019

Department for Education (2013). Citizenship programmes of study: key stages 3 and 4 National curriculum in England. https://assets.publishing.service.gov. uk/government/uploads/system/uploads/attachment_data/file/239060/ SECONDARY_national_curriculum_-_Citizenship.pdf

Department for Education (2014). Promoting fundamental British values as part of SMSC in Schools Departmental Advice for Maintained Schools. DFE-00679-2014

Dimensions (2016). \#'m with Sam. https://www.dimensions-uk.org/case-study/ imwithsam-experiences-hate-crime/ Accessed 31 Oct 2019

Garrison H (2008). Adolescents' perceptions of the sociocultural construct of disability when responding to literature: "Of Mice and Men". Fordham University

Gross Z (2012). Killing words; the anti-filicide toolkit. [online] The Autistic Self Advocacy Network. https://autisticadvocacy.org/projects/community/mourning/ anti-filicide. Accessed 8 Aug 2019

Gurko L (1998). The war between good and evil. The Greenhaven Press Literary Companion to American Literature. Literary Companion Series. Greenhaven Press

Hall E (2019) A critical geography of disability hate crime. Area 51(2):249-256

House of Commons House of Lords Joint Committee on Human Rights The detention of young people with learning disabilities and/or autism (2019). https://publications.parliament.uk/pa/jt201919/jtselect/jtrights/121/121.pdf. Accessed 22nd Jan 2020

Hughes K, Bellis MA, Jones L, Wood S, Bates G, Eckley L, McCoy E, Mikton C, Shakespeare T, Officer A (2012). Prevalence and risk of violence against adults with disabilities: a systematic review and meta-analysis of observational studies. Lancet https://doi.org/10.1016/S0410-6736(11)61851-5

Iyer A (2007) Depiction of intellectual disability in fiction. Adv Psychiatr Treat 13 (2):127-133. NB very good on other autistic characters and portrayal of them Jensen-Moulton S (2012) Intellectual disability in Carlisle Floyd's Of Mice and Men. Am Music 30(2):129-156

Kennedy TM, Menten T (2010). Reading, writing, and thinking about disability issues: five activities for the classroom. Engl J 100(2):61-67

Khomami N (2012). John Steinbeck's writing shouldn't be used in death row cases, says son [online]. The Telegraph. https://www.telegraph.co.uk/culture/books/ booknews/9462677/John-Steinbecks-writing-shouldnt-be-used-in-deathrow-cases-says-son.html. Accessed 21 Aug 2019

Kneen J, Foley J, Kelly L, Smith L, Thomas H, Watson A, Chapman S (2019). Top Ten Texts: what are the most common texts studied in years 7-9 and what are their features? Poster presentation, NATE ITE conference, 21 November 2019

Kupetz J (2016). Disability ecology: re-materializing US fiction from 1890-1940. Dissertation, University of Michigan

Lawrence C (2019) "I can be a role model for autistic pupils": investigating the voice of the autistic teacher. Teach Educ Adv Netw J 11(2):50-58

Linton S (1998) Disability studies/not disability studies. Disabil Soc 13(4):525-539

Liptak A (2016). Supreme Court to consider legal standard drawn from 'Of Mice and Men'. New York Times

Loftis SF (2015). Imagining autism: fiction and stereotypes on the spectrum. Indiana University Press

Loftis SF (2016). The autistic victim: Of Mice and Men. In: Davis LJ (ed) Disabillity studies reader, 5th edn. Routledge, New York, pp. 470-480

Long MCB (2013) Of Mice and Men, Fairy Tales, and Legends: a reactionary ethical proposal to storytelling and the Briseño cactors. Geo J Leg Ethics 26:859

Luciano S, Savage RS (2007) Bullying risk in children with learning difficulties in inclusive educational settings. Can J Sch Psychol 22(1):14-31

McCabe LL (2014) Representations of disability in Of Mice and Men and One Flew Over the Cuckoo's Nest: avoiding handicapism in the classroom. Doctoral dissertation, The Graduate School, Stony Brook University, Stony Brook

McCarthy C, Mitchell F, Rutherford C (2008). Disability equality: promoting positive attitudes through the teaching of the National Curriculum. Children's Society
McMahan J (1996) Cognitive disability, misfortune, and justice. Philos Public Aff 25(1):3-35

McMahan J (2002) The ethics of killing: problems at the margins of life. Oxford University Press, USA

Milton DE, Bracher M (2013) Autistics speak but are they heard. J BSA Medsoc Group 7:61-69

Murray S (2008). Representing autism: culture, narrative, fascination. Oxford University Press

National audit office (2018). https://www.nao.org.uk/press-release/convertingmaintained-schools-to-academies/

Perry J (1968) Adapting a novel to the stage. Engl J 57(9):1312-1315

Rosenblatt L (1938) Literature as exploration. Appleton-Century, New York

Singer P (1995). Animal liberation. Random House

Steinbeck J (1937a) Of Mice and Men. Pearson Longman Plain Edition, 10th impression, 2010, Essex, England

Steinbeck J (1937b) Of Mice and Men. Warner/Chappell Plays, reprinted 1998, London

Steinbeck J (1988). Conversations with John Steinbeck. University Press of Mississippi

Stevenson JL, Harp B, Gernsbacher MA (2011). Infantilizing autism. Disabil Stud Q $31(3)$

Swenson S (2019) New eugenics, old problems. J Policy Pract Intellect Disabili 16 (2):141-143

Thomas C (2007). Sociologies of disability and illness: contested ideas in disability studies and medical sociology. Macmillan International Higher Education

Wilson R (2016). Goodbye Lennie and George - I, for one, will miss Of Mice and Men [online]. The Guardian. https://www.theguardian.com/teacher-network/ 2016/may/08/goodbye-lennie-and-george-i-for-one-will-miss-of-mice-andmen. Accessed 21 Aug 2016

Wing, L. (1996). Autistic spectrum disorders

\section{Competing interests}

The author declares no competing interests.

\section{Additional information}

Correspondence and requests for materials should be addressed to C.L.

Reprints and permission information is available at http://www.nature.com/reprints

Publisher's note Springer Nature remains neutral with regard to jurisdictional claims in published maps and institutional affiliations.

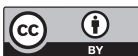

Open Access This article is licensed under a Creative Commons Attribution 4.0 International License, which permits use, sharing, adaptation, distribution and reproduction in any medium or format, as long as you give appropriate credit to the original author(s) and the source, provide a link to the Creative Commons license, and indicate if changes were made. The images or other third party material in this article are included in the article's Creative Commons license, unless indicated otherwise in a credit line to the material. If material is not included in the article's Creative Commons license and your intended use is not permitted by statutory regulation or exceeds the permitted use, you will need to obtain permission directly from the copyright holder. To view a copy of this license, visit http://creativecommons.org/ licenses/by/4.0/.

(C) The Author(s) 2020 